\title{
肺癌肺切除後脳転移症例の検討
}

\section{Patients with Brain Metastases after Lung Cancer Surgery}

別所俊哉・三好新一郎** ・ 前部屋進自・鈴間孝臣・平井一成

谷野裕一・吉増達也・有本潤司 $\cdot$ 内藤泰顯 $\cdot$ 上松右二*

\begin{abstract}
要旨 : 364例の肺癌肺切除例中，術後に脳転移を来した症例は35例 $(9.6 \%)$ で単発転移例が20例 $(57.1 \%)$, 多発転移例が15例 $(42.9 \%)$ であった。脳転移に対する手術は18例 $(51.4 \%) に$ 行われた. 手術群の中間生存期間(MST)は 9.5 力, 5 生率は $20.0 \%$ あっった。一方非手 術群ではMSTは 4 力月で, 13 力を越える生存例はなく, 予後不良であった。手術群に おける予後因子は, 脳以外の他臓器転移の有無であった。脳転移手術例中, 3 年以上生 存した長期生存例は 5 例 $(27.8 \%)$ で, 肺切除後のDFIが平均 30.6 月と長く, 脳転移数は 単発で, 全例脳以外に転移巣を認めなかった。また,このうち 4 例に脳転移に対する手 術が 2 回以上行われていた。このような症例に対して積極的に手術を行うことが予後向 上につながると考える。
\end{abstract}

〔肺癌 $38(3): 205 \sim 213,1998$ 〕

Key words : Lung cancer, Brain metastasis, Surgical treatment

\section{はじめに}

脳は原発性肺癌の遠隔転移の好発部位である と言われている ${ }^{1)}$. 脳転移診断後, 無治療の場合 の生命予後は $2 \sim 4$ 力月と不良で2), 多発例の外 科治療に関しては議論のあるところであるが, 単発例に対しては積極的な切除術が行われてい $る^{3)}$. 我々も以前から肺癌肺切除後の脳転移例に 対して, 積極的な外科治療を行ってきた4). 本論 文では肺癌肺切除後の脳転移例の臨床像, 治療 成績, 予後因子, および長期生存例について検 討を行った。

\section{対象および方法}

1985年 1 月から1995年12月までに，当科で手

和歌山県立医科大学第 1 外科

$\begin{array}{ccc}* & \text { 同 } & \text { 脳神経外科 } \\ * & \text { 大阪大学第 } 1 \text { 外科 } & \end{array}$

術を行った原発性肺癌364例中, 肺切除後にCT 検査で脳転移と診断された 35 例 $(9.6 \%)$ を対象と した。脳転移に対する手術適応は, 脳転移巣が 単発であり，脳以外には転移のないことを原則 としている。しかし(1)多発脳転移例でも，転移 巣が完全摘出可能と思われる症例, (2)完全摘出 ができなくても, 主病巣の切除により脳症状の 改善が期待される症例, (3)脳以外の他蔵器転移 例でも, 脳転移巣の切除により 6 力月以上の生 存が可能と考えられる症例に対しては積極的に 手術を行った。

脳転移診断後の生存率は, 手術群は手術日を, また非手術群は脳転移発見日を基準日として, Kaplan-Meier法で算出した. 各群間の生存率の 差の検定は $\log$-lank testを用い，また各群間の 頻度の差の検定は $\chi^{2}$ 検定にて行った. $\mathrm{P}<0.05$ を もって統計学的有意差ありとした。 
Table 1. Patients who underwent lung resection for primary lung cancer.

\begin{tabular}{ccc}
\hline & $\begin{array}{c}\text { Patients with brain } \\
\text { metastasis }\end{array}$ & $\begin{array}{c}\text { Patients with } \\
\text { lung resection }\end{array}$ \\
\hline Total no. of patients & 35 & 364 \\
\hline Sex : M/F & $24 / 11$ & $281 / 83$ \\
\hline Age & & \\
Mean (range) & $62.5(40-78)$ & $64.6(30-88)$ \\
\hline Histology & & \\
Adeno. & $20(57 \%)$ & $159(43.7 \%)$ \\
Squamous & $7(20 \%)$ & $159(43.7 \%)$ \\
Large & $3(8.6 \%)$ & $20(5.5 \%)$ \\
Small & $3(8.6 \%)$ & $16(4.4 \%)$ \\
Adenosquamous & $1(2.9 \%)$ & $4(1.1 \%)$ \\
Adeno+Small & $1(2.9 \%)$ & \\
\hline Pathological stage & & \\
I & $5(14.3 \%)$ & $172(47.3 \%)$ \\
II & $4(11.4 \%)$ & $30(8.2 \%)$ \\
III A & $20(57.1 \%)$ & $127(34.8 \%)$ \\
IIIB & $6(17.1 \%)$ & $30(8.2 \%)$ \\
IV & 0 & $4(1.1 \%)$ \\
\hline
\end{tabular}

Adeno. : adenocarcinoma, Squamous : squamous cell carcinoma, Large : large cell carcinoma, Small : small cell carcinoma, Adenosquamous : adenosquamous carcinoma, Adeno + Small : adenocarcinoma + small cell carcinoma

\section{結 果 \\ (1)臨床像}

肺癌肺切除後の脳転移症例35例の臨床像を Table

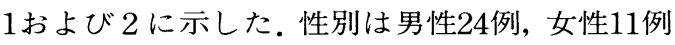
で，平均年㱓は62.5歳( $40 \sim 78$ 歳)であった。肺 癌の組織型は腺癌が20例 $(57 \%)$ で最も多く，以 下扁平上皮癌 7 例 $(20 \%)$, 大細胞癌 3 例 $(8.6 \%)$, 小細胞癌 3 例 $(8.6 \%)$, 腺扁平上皮癌 1 例 $(2.9 \%)$, 腺癌と小細胞癌との混合型 1 例 $(2.9 \%)$ であった. 組織型による発生率は扁平上皮癌が $4.4 \%(7 / 159)$ に対して非扁平上皮癌が $13.7 \%(28 / 205) て ゙$, 扁 平上皮癌症例において有意に脳転移の発生率が 低かった $(\mathrm{P}=0.02)$ 。病期では, I 期 : $5 / 172$ $(2.9 \%)$, II 期 : $4 / 30(13.3 \%)$, III A期 : 20/127 (15.7\%), IIIB期 : $6 / 30(20.0 \%)$ で, I + II 期 症例に比較し III期症例の発生率が有意に高かっ た $(\mathrm{P}<0.0001)$.また I 期の 5 例は腺癌が 2 例, 扁平上皮癌, 大細胞癌および小細胞癌がそれぞ れ 1 例であった。

肺切除から脳転移が診断されるまでの期間は
1 年以内が 23 例 $(65.7 \%)$ で， 1 年から 2 年が 5 例 $(14.3 \%), 2$ 年から 3 年が 5 例( $14.3 \%), 3$ 年から 4 年が 2 例 $(5.7 \%)$ であった。脳転移の発 見動機は症状が33例 $(94.3 \%), \mathrm{CEA}$ の上昇が認 められ頭部CTにて診断されたものが 2 例 $(5.7 \%)$ であった。脳転移の初発症状は, 片麻瘏・四肢 脱力が 11 例, 嘔気 - 頭痛が 8 例, 感覚障害 4 例, 意識障害 3 例，めまい 3 例，その他 4 例であっ た.CTによる脳転移数は, 単発が20例( $57.1 \%)$, 多発が15例 $(42.9 \%)$ で, 単発20例中14例 $(70.0 \%)$, 多発15例中 4 例 $(26.7 \%)$ の計18例に対して手術 が行われた。単発脳転移例で手術が行われなか った理由は，6 カ月以上の生存を望めない脳以 外の他臓器転移の存在が 4 例, PS不良が 1 例, 不明が 1 例であった。

\section{(2)脳転移巣に対する治療法および成績}

脳転移巣に対する治療法をTable 3に示した。 手術例のうち術前 CTで単発転移と診断された 14 例中, 1 例に䯣膜播種を認女主病巣のみの摘出 を行った。その他の単発転移13例の術式は, 腫 
Table 2. The characteristics of patients who had brain metastasis after lung resection for primary lung cancer.

\begin{tabular}{|c|c|c|}
\hline \multicolumn{3}{|c|}{ (1) Interval between lung and brain operations } \\
\hline & $\leqq 1($ years $)$ & $23(65.7 \%)$ \\
\hline & $1 \sim 2$ & $5(14.3 \%)$ \\
\hline & $2 \sim 3$ & $5(14.3 \%)$ \\
\hline & $3 \sim 4$ & $2(5.7 \%)$ \\
\hline \multirow[t]{3}{*}{ (2) } & Reason for detection of brain metastases & \\
\hline & neurological symptoms & $33(94.3 \%)$ \\
\hline & CEA elevation & $2(5.7 \%)$ \\
\hline \multirow[t]{7}{*}{ (3) } & Initial neurological symptoms & \\
\hline & hemiplegia, weakness of muscle power & $11(33.3 \%)$ \\
\hline & nausea, headache & $8(24.2 \%)$ \\
\hline & sensory disturbance & $4(12.1 \%)$ \\
\hline & disturbance of consciousness & $3(9.1 \%)$ \\
\hline & vertigo & $3(9.1 \%)$ \\
\hline & others & $4(12.1 \%)$ \\
\hline \multirow[t]{3}{*}{ (4) } & No of brain metastases by CT & \\
\hline & single & $20\left(14^{*}\right)$ \\
\hline & multiple & $15\left(4^{*}\right)$ \\
\hline
\end{tabular}

瘍切除が11例(全摘 6 例, 亜全摘 5 例), 温熱破 壊術が 2 例であった。温熱破壊術とは，腫瘍の 位置をCT定位脳手術法による方法で計測した後, $5 \mathrm{~mm}$ 程度の穿頭を行い, その部より外径 $3 \sim 4$ $\mathrm{mm}$ の電極針を腫瘍の中心部に挿入する.次いで 電極の先端部の温度を $80^{\circ} \mathrm{C}$ に保ち， 5 分間の高 周波電流の通電を行い腫瘍を温熱凝固する方法 である ${ }^{5)}$. 腫瘍の完全切除が行われた 6 例中, 術 後CTで脳内再発が確認された症例は 3 例(腫瘍 切除部再発 2 例, 新病変 1 例)であった。一方多 発例 4 例の治療法は, 主病巣のみの摘出が 2 例, 温熱破壊術が 1 例, 2 病巣例で一方に腫瘍摘出 を，もう一方に温熱破壊術を行ったのが 1 例で あった。脳転移手術後, 再発病巣に対しては積 極的に再手術を行った。脳転移手術回数は 1 回 が10例， 2 回が 3 例， 3 回が 3 例， 4 回が 2 例 で, 平均1.8回の手術が行われた。

術後補助療法は, 単発脳転移例においては, 全脳照射が 1 例, 化学療法が 7 例, 無治療が 5 例であった。化学療法の内訳はMitomysin C, Vindesine, Cisplatinの 3 者併用化学療法 (MVP 療法)が 1 例, UFTが 6 例であった. 多発脳転移 例では, 全脳照射が 2 例, 無治療が 2 例であっ
Table 3. Therapy for brain metastases.

\begin{tabular}{lc}
\hline ( I) Operative group & 18 \\
(1) Single metastasis & 13 \\
(a) Total resection & 6 \\
(b) Subtotal resection & 5 \\
(c) Thermal destruction & 2 \\
(2) Single metastasis + meningeal dissemination & 1 \\
(a) main tumor resection & 1 \\
(3) Multiple metastases & 4 \\
(a) Main tumor resection & 2 \\
(b) Thermal-destruction & 1 \\
(c) Tumor resection +Thermal-destruction & 1 \\
\hline
\end{tabular}

Postop. therapy

(1) WBRT 3

(2) Chemotherapy 7

(3) WBRT + Chemotherapy 1

(4) no anticancer therapy 7

(II) Non-operative group 17

(1) Radiotherapy 5

\begin{tabular}{lll} 
(a) WBRT & 4 & \\
(b) $\gamma$-knife & 1 & \\
(2) Chemotherapy & & 2 \\
(3) WBRT + Chemotherapy & & 1 \\
(4) No anticancer therapy & & 9 \\
\hline
\end{tabular}

WBRT ; Whole brain radiation therapy 
Fig. 1. Survival curves of patients with brain metastases after lung resection for primary lung cancer.

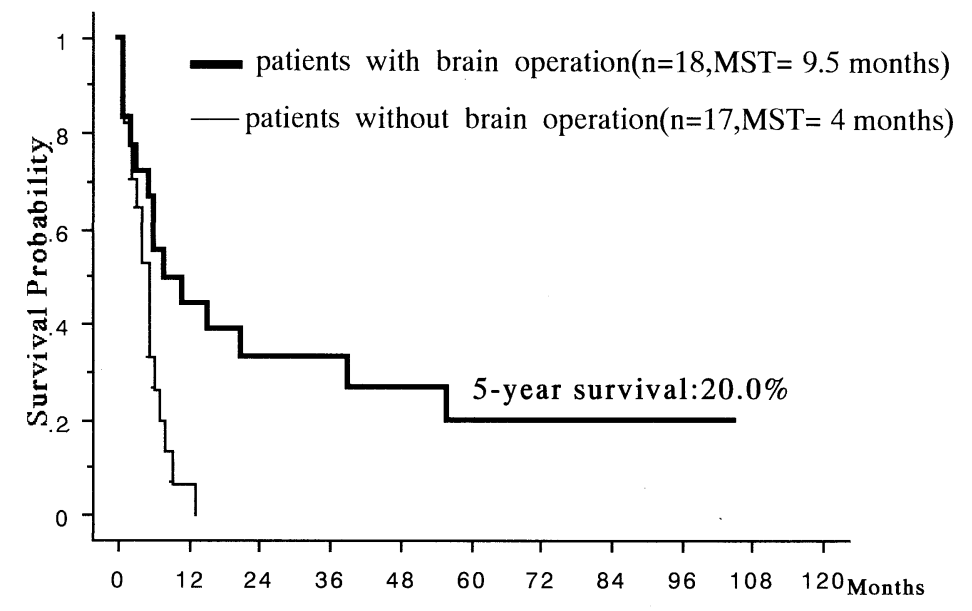

Table 4. Prognostic factors of patients who underwent operation for brain metastases.

\begin{tabular}{ccccc}
\hline Variables & & $\begin{array}{c}\text { No. of } \\
\text { Patients }\end{array}$ & $\begin{array}{c}\text { MST from Brain Op. } \\
\text { (month) }\end{array}$ & P-value \\
\hline Histology & $\mathrm{Ad}$ & 10 & 18 & $\mathrm{NS}$ \\
LN meta & $\mathrm{Sq}$ & 5 & 6 & $(\mathrm{P}=0.58)$ \\
& $(+)$ & 6 & 7 & $\mathrm{NS}$ \\
DFI (year) & $(-)$ & 12 & 16 & $(\mathrm{P}=0.54)$ \\
& $>1$ & 10 & 6 & $\mathrm{NS}$ \\
No. of Metastasis & single & 8 & 20 & $(\mathrm{P}=0.33)$ \\
Resectability & multiple & 5 & 21 & $\mathrm{NS}$ \\
Metastasis to & incomplete & 6 & 6 & $(\mathrm{P}=0.09)$ \\
other organs & $(+)$ & 5 & 56.5 & $\mathrm{NS}$ \\
\hline Ad & $(-)$ & 13 & 5 & $\mathrm{P}=0.20)$ \\
\hline
\end{tabular}

Ad : adenocarcinoma, $\mathrm{Sq}:$ squamous cell carcinoma

DFI : disease free interval, MST : median survival time

た。また髄膜播種例においては, MVP療法と全 脳照射を行った。

単発手術例13例中現在までに 9 例が死亡し, その死因は肺癌死 7 例 (脳 5 例, 肺 2 例), 他病 死 1 例, 不明 1 例であった。多発例 4 例中 1 例 に 4 回の脳転移手術を行い 15 力の生存を得た が，他の 3 例は術後 $1,3,6$ 力にそれぞれ死 亡した。髄膜播種例は脳転移術後 11 力後に脳 転移により死亡した。

一方非手術群の治療法は, 放射線治療が 5 例 (全脳照射 4 例, $\gamma$ ナイフ 1 例), 化学療法が 2 例, 全脳照射及び化学療法が 1 例, 無治療が 9 例で
あった。

手術群の脳転移初回外科治療からの中間生存 期間(Median Survival Time : MST)は9.5力月 で，5生率は $20.0 \%$ であった。一方非手術群の MSTは 4 力月で, 13 力月を越える生存例はなか った(Fig. 1).

(3)脳転移手術例の予後因子

脳転移手術例の予後因子につき, 組織型, リン 八瀄転移の有無, 肺切除から脳転移手術までの期 間(Disease free interval : DFI), 脳転移数, 脳 転移手術の根治度，および脳以外の他臟器転移 の有無について検討を行った(Table 4).組織型, 
Table 5. Five patients with brain operations who survived more than 3 years.

\begin{tabular}{cccccccccr}
\hline & $\begin{array}{c}\text { age/sex } \\
(\mathrm{yr})\end{array}$ & Histology & p-TN & $\begin{array}{c}\text { DFI } \\
(\mathrm{mo})\end{array}$ & $\begin{array}{c}\text { No. of } \\
\text { Brain } \\
\text { Meta }\end{array}$ & $\begin{array}{c}\text { Meta. to } \\
\text { Other } \\
\text { Organs }\end{array}$ & $\begin{array}{c}\text { No. of } \\
\text { Brain } \\
\text { Op. }\end{array}$ & $\begin{array}{c}\text { Post } \\
\text { Op. } \\
\text { therapy }\end{array}$ & $\begin{array}{c}\text { Survival } \\
\text { after } \\
\text { craniotomy }\end{array}$ \\
\hline $1:$ & $60 / \mathrm{M}$ & Large & T3N0 & 6 & 1 & $(-)$ & 3 & UFT & $105 ;$ alive \\
$2:$ & $59 / \mathrm{F}$ & Ad & T1N1 & 46 & 1 & $(-)$ & 4 & UFT & $59 ;$ alive \\
$3:$ & $63 / \mathrm{M}$ & Sq & T2N2 & 17 & 1 & $(-)$ & 1 & UFT & $59 ;$ alive \\
$4:$ & $60 / \mathrm{F}$ & Ad & T1N1 & 34 & 1 & $(-)$ & 2 & UFT & $56 ;$ died \\
$5:$ & $50 / \mathrm{M}$ & Ad & T1N2 & 40 & 1 & $(-)$ & 3 & UFT & $39 ;$ died \\
\hline
\end{tabular}

Large : large cell carcinoma, Ad : adenocarcinoma, $\mathrm{Sq}:$ squamous cell carcinoma

DFI : disease free interval (interval between thoracotomy and craniotomy)

Fig. 2 .

Brain computed tomography (CT) scans of patient 1 shown in table 5 . (a) : First preoperative computed tomography (CT) scan shows a mass in the right cerebellum.

(b) : CT scan before the second operation (4 month after first operation) shows a mass in the same region as the original site.

(c) : CT scan before the third operation shows a new metastasis in the left parietal region.

(d) : CT scan after the third operation shows no tumor.

Brain operations were done in total three times for this patient and he is surviving 105 months after the first craniotomy.

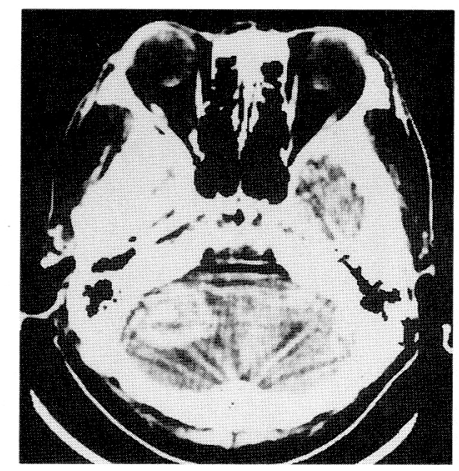

a)

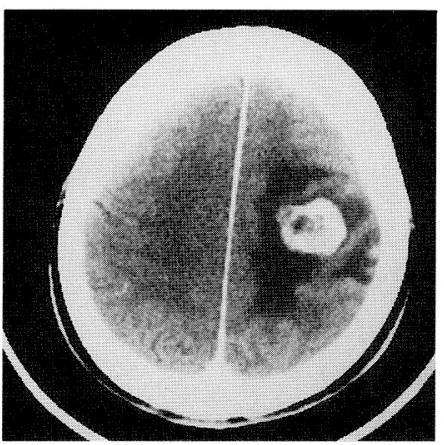

c)

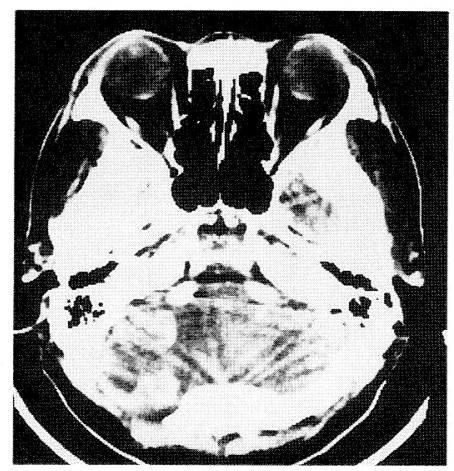

b)

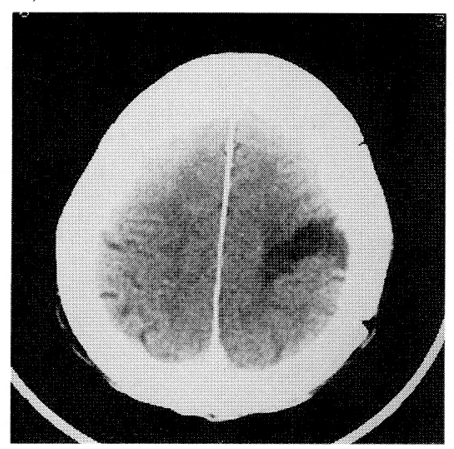

d)
リンパ節転移の有無, DFI, 脳転移数, 脳転移手 術の根治度に関しては生存率に有意差を認めな かった。一方脳以外の他臟器転移の有無におい ては, 脳以外の他藏器に転移のない群のMSTは 56 力, 5 生率は $41.7 \%$ で, 他臓器転移のある 群のMSTは 5 力月で, 脳転移手術後 8 力月を越之 る生存例はなかった。脳以外の他臓器に転移がな い群が，ある群に比し有意に予後良好であった。

\section{(4)長期生存例の検討}

脳転移手術例18例中, 脳転移手術後 3 年以上 生存した症例は 5 例(27.8\%)であった(Table 5). 組織型は腺癌が 3 例, 扁平上皮癌と大細胞癌が
それぞれ 1 例であった。原発巣の病理病期はII 期が 2 例, III a期が 3 例で全例治瘾切除が行われ ていた. DFIは 1 年以内が 1 例のみで, 平均 30.6 力月と比較的長かった。脳転移数は全例単発で, 脳転移発見時, 全例脳以外の他蔵器に転移を認 めなかった。脳転移に対する手術は 1 回から 4 回, 平均2.6回行われていた。術後, 全例に経口 抗癌剂であるUFTが投与されていたが，放射線 治療は行われていなかった。

症例 1 はまず右小脳に転移を認め(Fig. 2a) 切 除したが, 切除部に再発を認め(Fig. 2b), 再切 除を行った。次いで左側頭葉に新しい転移巣(Fig. 
Fig. 3.

Brain computed tomography (CT) scans or magnetic resonance image (MRI) of patient 2 shown in table 5 . (a) : Preoperative MRI shows a mass in the left frontal lobe.

(b) : MRI before the second operation shows a new tumor in the frontoparietal site.

(c) : MRI before the third operation shows mass in the first resected tumor site.

(d) : CT scan before the fourth operation shows a tumor in the latest operative site and the tumor was removed.

This patient is alive in 59 months after the first craniotomy.

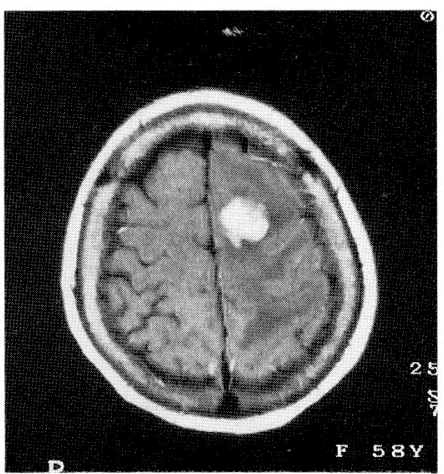

a)

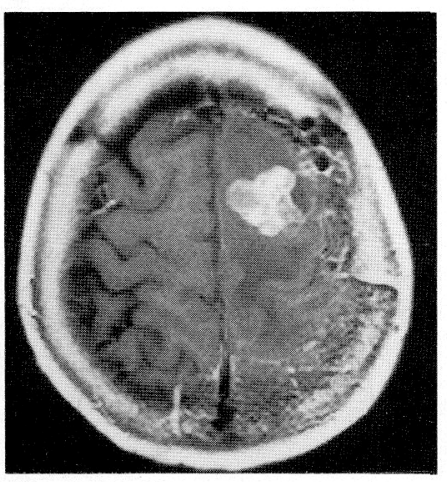

c)

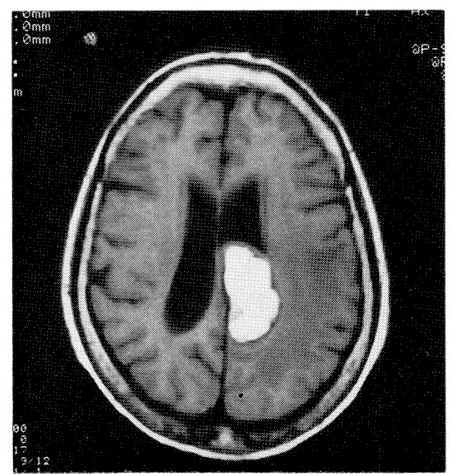

b)

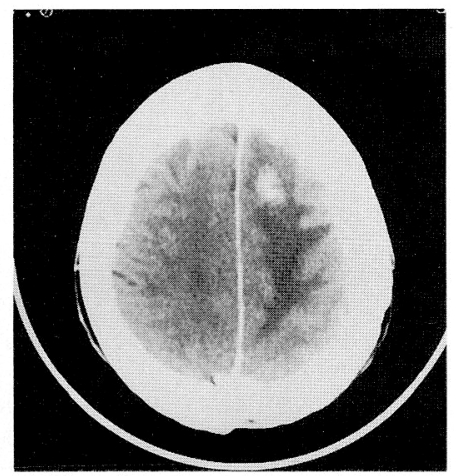

d) 2c)が出現し, 切除した (Fig. $2 \mathrm{~d})$. その後は再発 なく初回脳転移手術より105力月生存中である。 症例 2 はまず左前頭葉に転移を認め(Fig. 3a)切 除した。次いで前側頭葉に新しい転移巣(Fig. 3b) を認め，切除した。その後第 1 回目の腫瘍切除 部に再発をきたし(Fig. 3c)切除した.さらに再 び同じ部位に再発(Fig. 3d)し切除した. 以後は 再発なく, 初回脳転移手術より59力月生存中で ある。症例 3 は腫瘍が深部に存在していたため 全脳照射後, 腫瘍に温熱破壊術を行った後, 59 力月再発なく生存中である。症例 4 は, 左側脳 室近傍に転移を認めたが，腫瘍が深部にあるた め温熱破壊術を行った。その後左前頭葉に新病 変を認め切除したが，多発性脳転移をきたし， 初回脳転移手術後56力月脳転移で死亡した。症 例 5 は左側頭葉に転移を認め切除したが，切除 部に再発し再切除を行った。その後，多発性脳 転移をきたし温熱破壊術を行ったが，初回脳転 移手術後39力月, 脳転移により死亡した。

\section{考 察}

肺癌切除後の脳転移は, 文献上 $6.8 \%$ 15.0\% ${ }^{6) \sim 8)}$ に認められ，自験例でも364例中35例 $(9.6 \%)$ と 同等の頻度であった. The Ludwig Lung Cancer Study Group ${ }^{8)}$ は, I 期抢よびII 期切除非小細胞 肺癌1012例中63例が術後脳転移をきたしたが, 組織別発生率は，扁平上皮癌が $9 \%$ であったの に対して, 腺癌が19\%, 大細胞癌が18\%であり， 非扁平上皮癌症例に脳転移発生率が高かったと 報告している。またFiglin ら ${ }^{6)}$ はIII期までの非小 細胞肺癌切除後脳転移例154例を検討し, 非扁平 上皮癌とともに非T1N0肺癌が有意に脳転移の発 生率が高かったと報告している。我々の検討で は, 非扁平上皮癌 $(\mathrm{P}=0.02)$ およびIII期肺癌症例 $(\mathrm{P}<0.0001)$ が有意に脳転移の発生率が高かった。 また脳転移発生の $80 \%$ が術後 2 年以内であるこ とから, 肺切除後 2 年間は, 特に III期の非扁平 上皮肺癌症例に対しては, 脳転移に関する慎重 な経過観察が必要であると考之られた。

我々は 4 例の多発脳転移例に対して手術を行 
つた. 4 例中 1 例に 4 回の脳転移手術を行い 15 カ月の生存を認めたが, 他の 3 例は術後 6 力月 以内に死亡し, 予後不良であった。森川ら ${ }^{9}$ は肺 癌脳転移例 6 例 12 転移巣にガンマ・ナイフ治療 を行い, 奏効率が92\%と良好で, 重篤な合併症 もなかったと報告していることから，多発脳転 移例に対しては, ガンマ・ナイフ治療が良い適 応と思われる。

脳転移手術例の子後因子に関しては, Mussiら ${ }^{10)}$ は, 原発巣と脳転移巣のどちらにも手術が行わ れた肺癌脳転移例 52 例を検討し, リンパ節転移 除性例が陽性例に, 肺の葉切例が全摘例に比し 予後良好で, 脳転移切除例の生存率は, 原発巣 の進行度にかなり影響を受けると述べている。 また脳転移異時性発見例においては, 原発巣切 除から脳転移手術までの期間が 14.5 力以上例 が上記 2 因子に加之，予後良好な因子であった と報告している.Wronskiら ${ }^{11)}$ は肺癌の脳転移 切除例231例において, 最も予後良好な因子とし て, 原発巣の完全切除と脳以外に他藏器転移が ないことを挙げている。またその他に，年齢(60 歳未満), 女性, 良好なPS, テント上病変, 脳転 移完全切除などが, 有意な予後良好因子であっ たと報告している。我々の検討においても，脳 以外に他藏器転移のない群が有意に予後良好で あったが, リンパ節転移の有無, 肺切除から脳 転移手術までの期間 (DFI), 脳転移数, 脳転移巣 の完全切除の有無などにおいては, 予後に関し て有意差は認められなかった。しかし脳転移数

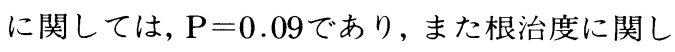
ては, 完全切除例のMSTが56.5力月に対して, 不完全切除例のMSTが11カ月とかなりの差を認 めた。また長期生存例では, 単発脳転移および 転移巣の完全切除が必要条件となっており, 脳 転移数および根治度に関しては, 今後症例数の 増加により, 有意差が生じる可能性が考えられ る。また一方 3 年以上の長期生存が得られた 5 例中 4 例は34力月以上のDFIを有し, DFIも予後 に重要な因子であると思われる。

堀口ら ${ }^{12)}$ は, 肺癌脳転移後 2 年以上の生存が 得られた 5 例中, 長期生存が得られた 2 例はど ちらも脳転移の再発に対して, 再切除が行われ
た症例であり, 一定の条件を満たす場合, 再発 脳転移に対しても積極的に治療を追加する意義 があると述べている. 自験例においても， 3 年 以上の長期生存例を脳転移手術例中 5 例 $(27.8 \%)$ に認め, そのうち 3 例が現在再発なく生存中 $(59$ 力月 105 力月)である。 その 3 例は, 原発巣に 対して根治術が行われ, かつ発見時他臓器転移 のない単発脳転移例であった。また 3 例中 2 例 に再発脳転移のため, 2 回あるいは 3 回の再手 術を行った. Bindal ら $^{13)}$ は48例の再発脳転移例 に対して手術を行い, 手術例のMSTが11.5力月 で非手術例に比べ有意に予後良好であったと述 べている，脳以外に転移がない単発転移例で, 完全切除可能と判断される場合, 切除部の再発 を含め, 手術回数に関係なく積極的に手術を行 うことが予後向上につながると思われる。実際 今回の我々の検討において,一症例に平均 1.8 回 の脳転移手術が行われており，それが 5 生率 20.0 \%が得られた大きな要因と思われる。

一方自験例で, 単発脳転移例で全摘を行った 6 例中, 脳内再発を 3 例 $(50 \%)$ に認めた。一般 に外科療法のみでは脳内再発率が高く, 術後の 補助療法について検討が行われている.DeAngelis $ら^{14)}$ は98例の単発脳転移切除例に対して, 術後 の全脳照射の効果について検討を行い, 脳内再 発率および中間生存期間は, 全脳照射群で $22 \%$, 20.6 力月, 非全脳照射群で46\%，14.4 カ月と全 脳照射群で良好であったと報告している.Smalley $ら^{15)}$ も, 85例の単発脳転移切除例で脳内再発率 および中間生存期間が，全脳照射群で $21 \%, 21$ 力月, 非全脳照射群で $81 \%, 11.5$ 力月と全脳照射 群で良好であったと述へててる.一方Armstrong $ら^{16)}$ は, 脳転移切除後の全脳照射により, 腫瘍 切除部の再発率は低下したが, 脳内転移率の低 下や生存率の向上は認めなかったと述べている. また浅井ら ${ }^{17)}$ は, 30Gy以上の全脳照射を受けた

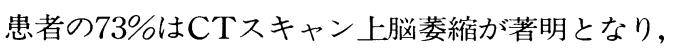
高率に痴呆を伴うと報告している.DeAngelisら ${ }^{14)}$ も, 術後全脳照射例で 1 年以上生存例のうち $11 \%$ に重篤な痴呆を認めたと報告している。このよ うに術後の全脳照射の意義に関しては, 照射後 の晚発性精神障害という重篤な副作用の問題も 
あり，今後さらなる検討が必要である。

化学療法に関しては, Ushioら ${ }^{18)}$ は全脳照射に Nitrosourea系薬荗とテガフールを併用すること により, 全脳照射単独に比較し有意に脳転移巣 の縮小が得られたと報告している。笠松ら ${ }^{19)}$ は 5 例の肺癌脳転移例に対してMVP(MMC, VDS, CDDP) 療法を行い, 全例で神経症状が改善し， 頭部CT上 5 例中 3 例に腫瘍の縮小効果があった と述べている．しかし化学療法の効果に対する 報告は少なく，今後さらに多くの検討が望まれ る。

\section{まとめ}

1985年 1 月から1995年12月までに肺切除を行 い，その後脳転移を来した35例を検討した。

(1)手術群18例のMSTは 9.5 力月, 5 生率 $20.0 \%$,
一方非手術群17例のMSTは 4 力月で, 13 力月を 越之る生存例はなく予後不良であった。

(2)手術群における予後因子は, 脳以外の他臓器 転移の有無であった。

(3) 3 年以上の長期生存例の 5 例は, 初回脳転移 発見時, 脳転移は単発で, 脳以外の他藏器転移 を認めなかった。また 5 例中 4 例に脳転移に対 する手術が 2 回以上行われていた。

以上より脳以外の他臟器転移がなく, 完全切 除可能な単発転移例に対しては, 手術回数に関 係なく積極的に手術を行うことが予後向上につ ながると思われた。

尚, 本論文の要旨は第13回日本呼吸器外科学会総会 $(1996$ 年 5 月, 仙台)に於いて発表した。
文

1) Yano $T$, Yokoyama $H$, Inoue $T$, et al : The first site of recurrence after complete resection in non-small-cell carcinoma of the lung. J Thorac Cardiovasc Surg 108 : 680-683, 1994.

2) 松谷雅生：脳転移の治療一肺癌脳転移を中心と して一. 外科治療 $63: 150-154,1990$.

3) Burt M, Wronski M, Arbit E, et al : Resection of brain metastases from non-small-cell lung carcinoma. J Thorac Cardiovasc Surg 103 : 399-411, 1992.

4) 前部屋進自, 西村 治, 横井秀樹, 他: 肺癌切 除後に脳転移をきたした症例の治療とその臨床 的評価. 肺癌 $29: 377-382,1989$.

5）横手英義，駒井則彦，中井易二，他：温熱によ 万定位的腫瘍破壊術. 機能的脳神経外科 27 : 59-64, 1988.

6) Figlin R, Piantadosi S, Feld R, et al : Intracranial recurrence of carcinoma after complete surgical resection of stage, I, II, and III non-small cell lung cancer. N Engl J Med $318:$ 1300-1305, 1988.

7) Yokoi K, Miyazawa N, Arai $T$ : Brain Metastasis in Resected Lung Cancer : Value of Intensive Follow-up With Computed
Tomography. Ann Thorac Surg 61 : 546-551, 1996.

8) The Ludwig Lung Cancer Study Group : Patterns of Failure in Patients with Resected Stage I and II Non-Small-cell Carcinoma of the Lung. Ann Surg $205: 67-71,1987$.

9) 森川哲行, 武内浩一郎, 藤野英世, 他 : 肺癌脳 転移に対するガンマ・ナイフ治療。日胸疾会誌 $33:$ 44-49, 1995.

10) Mussi A, Pistolesi M, Lucchi M, et al : Resection of single brain metastasis in nonsmall-cell lung cancer : prognostic factors. J Thorac Cardiovasc Surg 112:146-153, 1996.

11) Wronski M, Arbit E, Burt M, et al : Survival after surgical treatment of brain metastases from lung cancer : a follow-up study of 231 patients treated between 1976 and 1991. J Neurosurg 83 : 605-616, 1995.

12）堀口倫博, 野木村宏, 杉村久男, 他: 肺癌脳転 移例の検討. 肺癌 $30: 1013-1019,1990$.

13) Bindal RK, Sawaya R, Leavens ME, et al : Reoperation for recurrent metastatic brain tumors. J Neurosurg 83 : 600-604, 1995.

14) DeAngelis LM, Mandell LR, Thaler HT, et al: 
The Role of Postoperative Radiotherapy after Resection of Single Brain Metastases. Neurosurgery 24 : 798-805, 1989.

15) Smalley SR, Schay MF, Laws ER, et al : Adjuvant radiation therapy after surgical resection of solitary brain metastasis : association with pattern of failure and survival. Int J Radiat Oncol Biol Phys 13 : 1611-1616, 1987.

16) Armstrong BJ, Wronski M, Arbit GE, et al : Postoperative Radiation for Lung Cancer Metastatic to the Brain. J Clin Oncol 12 :
2340-2344, 1994.

17) 浅井昭雄, 松谷雅生, 高倉公朋, 他 : 脳腫瘍放 射線治療後の亜急性障害としての脳萎縮と痴呆。 癌の臨床 $33: 753-761,1987$.

18) Ushio $Y$, Arita N, Hayakawa $T$, et al : Chemotherapy of Brain Metastases from Lung Carcinoma : A Controlled Randomized Study. Neurosurgery $28: 201-205,1991$.

19）笠松美宏, 沢田 学, 瀬戸口純子, 他: 非小細胞肺 癌の脳転移に対するMitomycin C, Vindesine, Cisplatin併用化学療法(MVP療法)の検討. 肺癌 $30: 159-165,1990$.

（原稿受付 1998 年 2 月 16 日／採択 1998 年 5 月14日）

\title{
Patients with Brain Metastases after Lung Cancer Surgery
}

\author{
Toshiya Bessho ${ }^{1}$, Shinichiro Miyoshi ${ }^{3}$, Shinji Maebeya ${ }^{1}$ \\ Takaomi Suzuma ${ }^{1}$, Issei Hirai ${ }^{1}$, Hirokazu Tanino ${ }^{1}$ \\ Tatsuya Yoshimasu ${ }^{1}$, Junji Arimoto ${ }^{1}$, Yasuaki Naito ${ }^{1}$ \\ and Yuji Uematsu ${ }^{2}$
}

1. First Department of Surgery, 2. Department of Neurosurgery,

Wakayama Medical College,

3.First Department of Surgery,

Osaka University School of Medicine

\begin{abstract}
Thirty five patients with brain metastases after lung resection for primary lung cancer were retrospectively reviewed. Of there, 19 patients $(54.3 \%)$ had a solitary brain metastasis and 16 patients $(45.7 \%)$ had multiple brain metastases. Eighteen $(51.4 \%)$ of the 35 patients underwent brain operations. The five-year survival rate and median survival time (MST) were $20.0 \%$ and 9.5 months in patients with brain operations. In patients without brain operations, the MST was 4 months and no patients survived more than 13 months. The analysis of the several prognostic factors in the patients with brain operations revealed that only no metastases to other organs than brain at brain surgery significantly prolonged the survival. Five $(27.8 \%)$ of 18 patients with brain surgery survived more than 3 years. All had a solitary brain metastasis without metastases to other organs. Four of them underwent operations from two to four times for brain metastasis. Such an aggressive surgical treatment may permit long-term survival in patients with a single brain metastasis.
\end{abstract}

